\title{
A Personalized English Teaching Design Based on Multimedia Computer Technology
}

\author{
https://doi.org/10.3991/ijet.v15i08.13695 \\ Yan Zhao \\ Yantai Nanshan University, Yantai, China \\ ttftpy@163.com
}

\begin{abstract}
In the Internet age, the proliferation of multimedia computer technology (MCT) brings unprecedented opportunities to English teaching in colleges. This paper firstly carries out a questionnaire survey on the current status of personalized teaching of college English, and summed up the main problems with the current teaching mode. On this basis, the authors developed an MCT-based personalized English teaching design, with the aid of information technology (IT) and online teaching platform. To verify its effect, the proposed design was tested through contrastive experiment. The results show that the MCT-based personalized English teaching design could improve the interests and performance of English learning, and cultivate a good learning habit. In summary, this paper explores the personalized teaching of college English from both theoretical and practical angles, laying a good basis for highquality English teaching and personalized development of students.
\end{abstract}

Keywords-Multimedia computer technology (MCT), online platform, personalized English teaching design, teaching effect

\section{Introduction}

Under the trend of globalization, English, an important universal language, becomes an essential skill to international talents. However, there are many problems with the teaching of English as a second language, such as the poor teaching effect and the weak ability to practice the language. Educators around the world are striving to find the right teaching strategy to solve these problems.

With differences in personality and learning ability, college students vary greatly in the demand and acceptance of English learning. English teachers must teach students according their aptitude and demand, i.e. implement the strategy of personalized teaching [1]. To realize personalized teaching, college English teachers should recognize the individual differences and defects of students in English learning ability, treat students as equals, and fully tap their potential.

The idea of personalized teaching can be traced back to ancient times. Some educators advocated the thoughts of teaching students according to their aptitude and providing education for all people without discrimination [2]. In modern times, the first attempts to adapt teaching techniques to individual differences were made be- 
tween the 1960s and 1970s, creating individualized teaching system and instructions [3].

In the Internet age, the proliferation of multimedia computer technology (MCT) has changed how we live and learn, and brought new opportunities to personalized English teaching in colleges. The space for personalized teaching and learning has widened, thanks to computer technology and the Internet. Audiovisual, computerized, and programmed teachings are all personalized teaching modes based on computer technology [4].

The recent studies [5] mainly deal with the following aspects of personalized teaching: concept, connotation, features, means, modes and implementation methods. Some scholars explored personalized teaching from the angle of computer and information technology, including the design and implementation of personalized teaching systems, the analysis of student data on online learning platforms, and the recommendation of suitable learning resources [6].

In 2007, the Department of Higher Learning, Chinese Ministry of Education released the College English Teaching Requirements [7], calling for the transition to personalized English teaching in colleges. Since then, many Chinese researchers have tried to personalize the teaching of college English.

Some researchers [8] developed new personalized teaching modes for college English from the perspectives of teachers and students. One of these modes is thematic teaching, a strategy of quality education. Thematic teaching integrates English with the knowledge of other disciplines, and provides students with real communication environment outside the campus. This method can effectively enhance the learning efficiency. However, it is very difficult to implement and popularize this approach, unless stakeholders refresh their philosophy on development.

Some researchers [9] promoted personalized teaching and learning of English with modern education techniques like the MCT and the Internet technology (IT), marking the main trend of English teaching. This strategy replaces backboard writing with multimedia courseware, gathers rich language materials through online teaching, and creates a real linguistic environment. Nonetheless, the online teaching may be too complex to control, if the strategy is not meticulously designed [10].

Drawing on the relevant literature, this paper surveys the current status of college English teaching, and sums up the problems with the current teaching mode. On this basis, the authors developed an MCT-based personalized English teaching design, with the aid of IT and online teaching platform. Finally, the proposed design was verified through contrastive experiment.

\section{Questionnaire Survey}

This paper carries out a questionnaire survey to understand the current situation of personalized English teaching in colleges. The questionnaire was designed in reference to Aharony's research [11]. The survey targets non-English majors randomly selected from a college in Hangzhou, eastern China's Zhejiang province. All of them 
are freshmen, sophomores or juniors. A total of 500 questionnaires were issued, and $494(98.8 \%)$ valid responses were obtained.

\subsection{Current situation of English learning}

The statistics on the respondents' preference for English are plotted as Fig. 1. It can be seen that most only a few students hold a negative view of English. The favorable view of English is attributable to the international status of the language. The mastery of such a widely spoken language benefits future learning and work. Most college students aim to acquire necessary knowledge and skills through English learning. In other words, their motives of English learning are very utilitarian, which should be mitigated under teacher guidance.

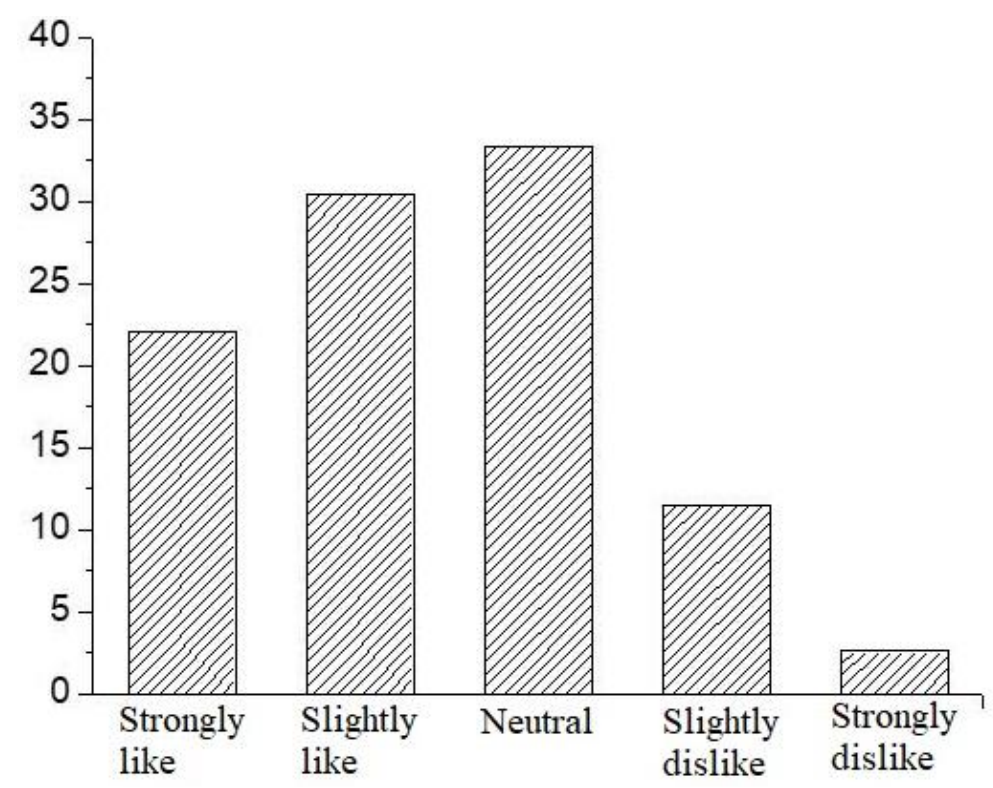

Fig. 1. Respondents' preference for English

\subsection{Current situation of English teaching}

The teaching method and effect directly affect the learning interest [12]. Fig. 2 presents how frequent the MCT is used by college English teachers. It can be seen that $70 \%$ of teachers often use the MCT to teach English, and only $1.05 \%$ have never utilized the technology in English teaching. Further investigation shows that $90 \%$ of college English teachers have used electronic whiteboard, more than that for any other multimedia tool.

Fig. 3 displays the survey results on teacher-student interaction. It can be seen that most teachers do not actively interact with students in the teaching process. Only $32.3 \%$ of teachers maintain active interaction with students. Meanwhile, $18.9 \%$ think 
little of teacher-student interaction, and $2.3 \%$ have never interacted with students. Our survey also reveals that most students do not communicate with teachers or classmates, even if they face some problems.

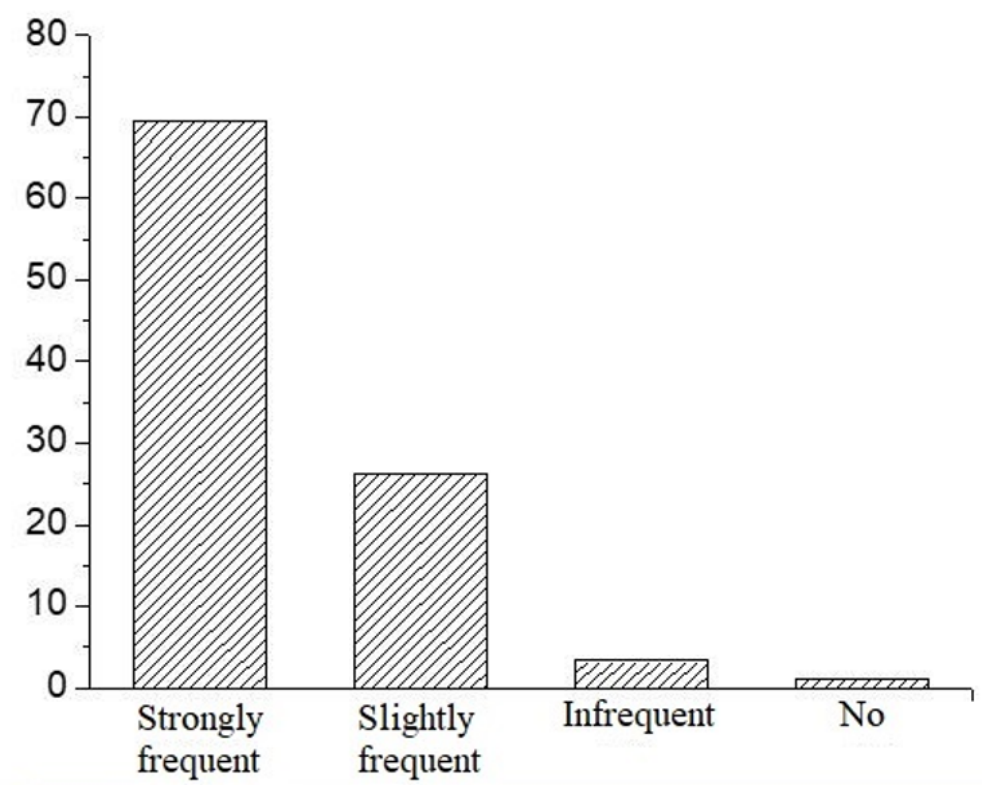

Fig. 2. Frequency of MCT utilization among college English teachers

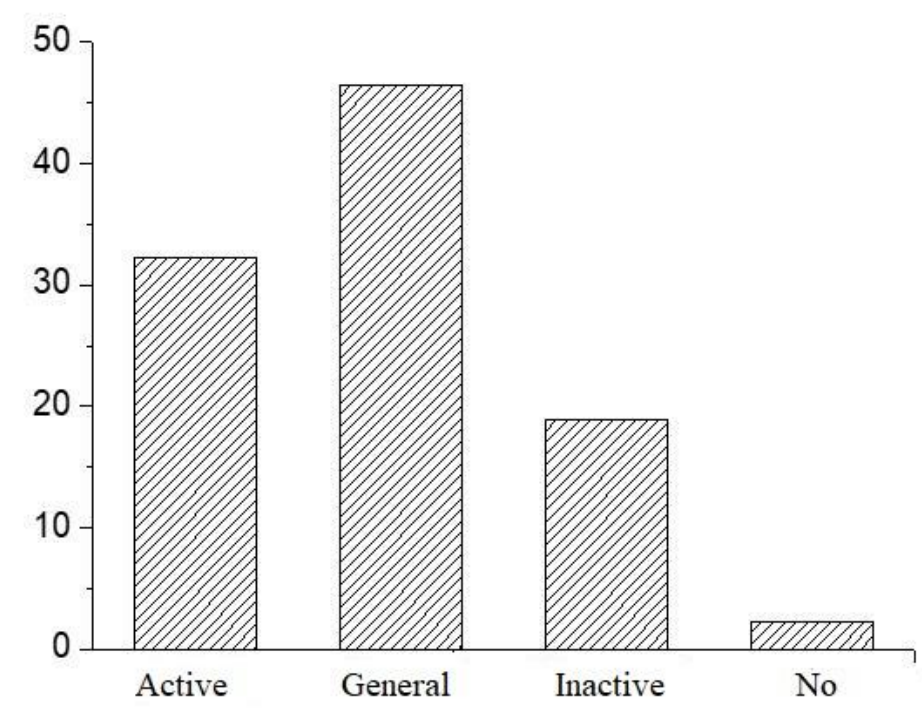

Fig. 3. Teacher-student interaction 


\subsection{Current status of personalized English teaching}

Fig. 4 shows the survey results on personalized teaching of college English. It can be seen that only $4.97 \%$ and $29.82 \%$ of college English teachers are strongly or slightly concerned about the learning styles, respectively. Thus, most teachers have not paid enough attention to learning style. Besides, multimedia and online resources have not been sufficiently utilized by college English teachers, most of whom still teach based on textbooks. Furthermore, many teachers now implement personalized English teaching, using the traditional method of group instruction, and most students (75\%) agree that personalized teaching helps them learn English.

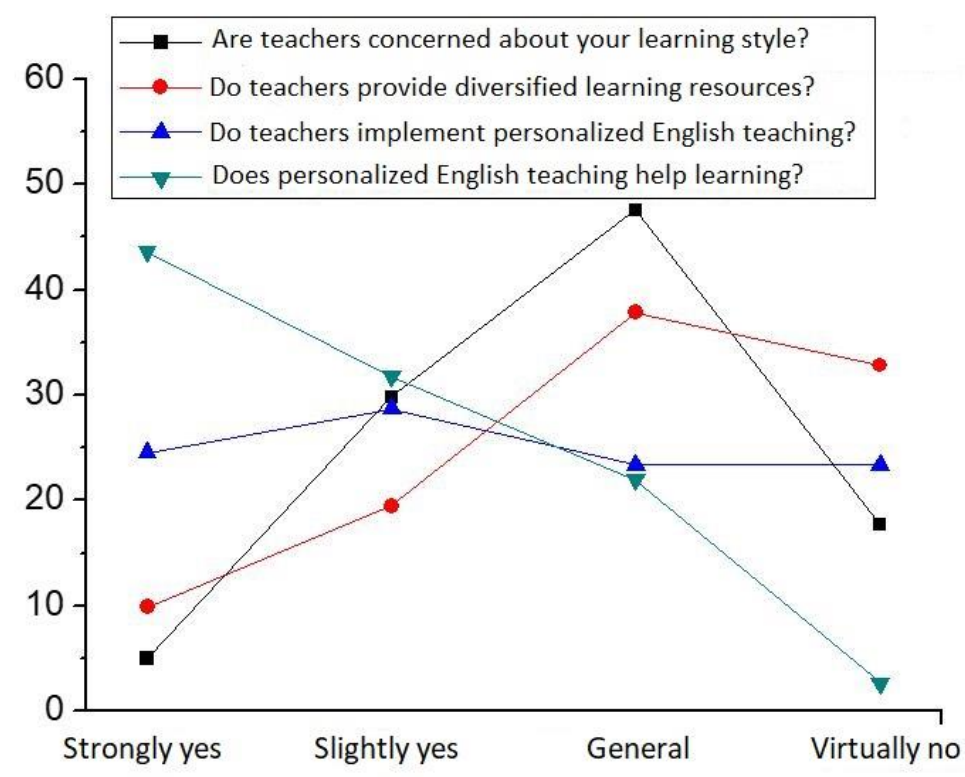

Fig. 4. The current status of personalized English teaching in colleges

Through the survey, the following problems were found in the current teaching mode of college English:

1) Despite the generally favorable views of English, most students have utilitarian motives for English learning. Their cognition and attitude of English learning should be corrected under teacher guidance.

2) Most teachers know how to MCT in English teaching, but have rarely utilized tools other than the electronic whiteboard. The students are only provided with a limited amount of learning resources. The teacher-student interaction should be further improved.

3) English teachers have not paid enough attention to learning styles in the teaching process, failing to implement highly individualized teaching methods and means. 


\section{$3 \quad$ MCT-Based Personalized English Teaching Design}

\subsection{Development and implementation}

Based on the survey results, this paper develops and implements an MCT-based personalized English teaching design from five aspects, namely, teaching preparation, pre-class personalized preview, in-class personalized Q\&A, post-class personalized review, and personalized data analysis \& feedback, with the aid of the IT and online teaching platform. The design aims to stimulate the learning interests and teaching efficiency of English.

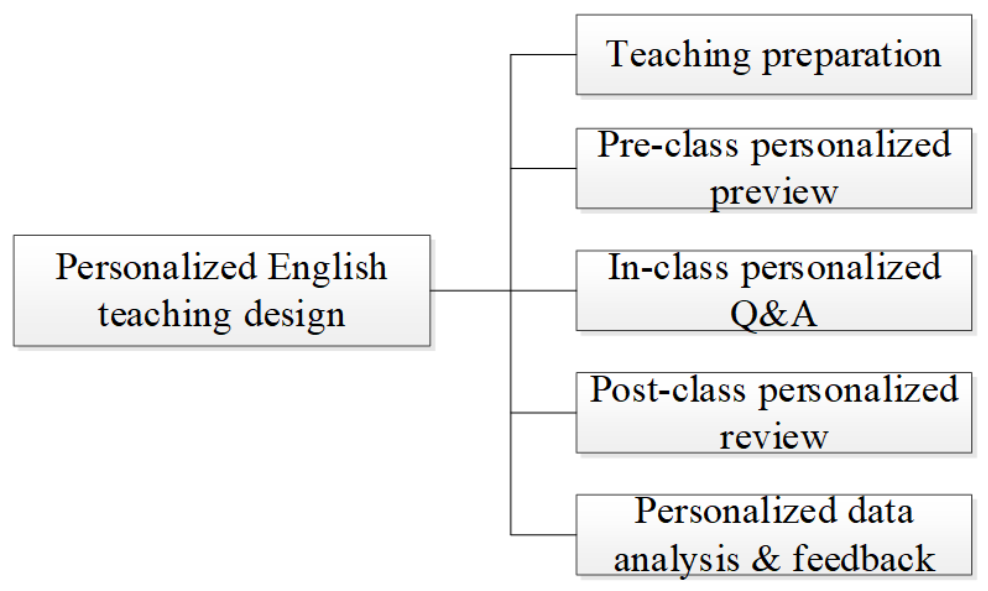

Fig. 5. MCT-Based personalized English teaching design

Teaching preparation: During teaching preparation [13], the teachers need to set out the teaching goals, select suitable teaching and evaluation methods, and design and develop teaching resources, according to the requirements of the syllabus and the actual situation of the students.

Here, two Grade 2 classes are selected from a college, and respectively taken as the experimental class and the control class. The two classes both have 53 students. The MCT-based personalized English teaching design and the traditional English teaching design were implemented in the experimental class and the control class, respectively. As shown in Fig. 6, the students in the control class had better English proficiency than those in the experimental class before the experiment. 


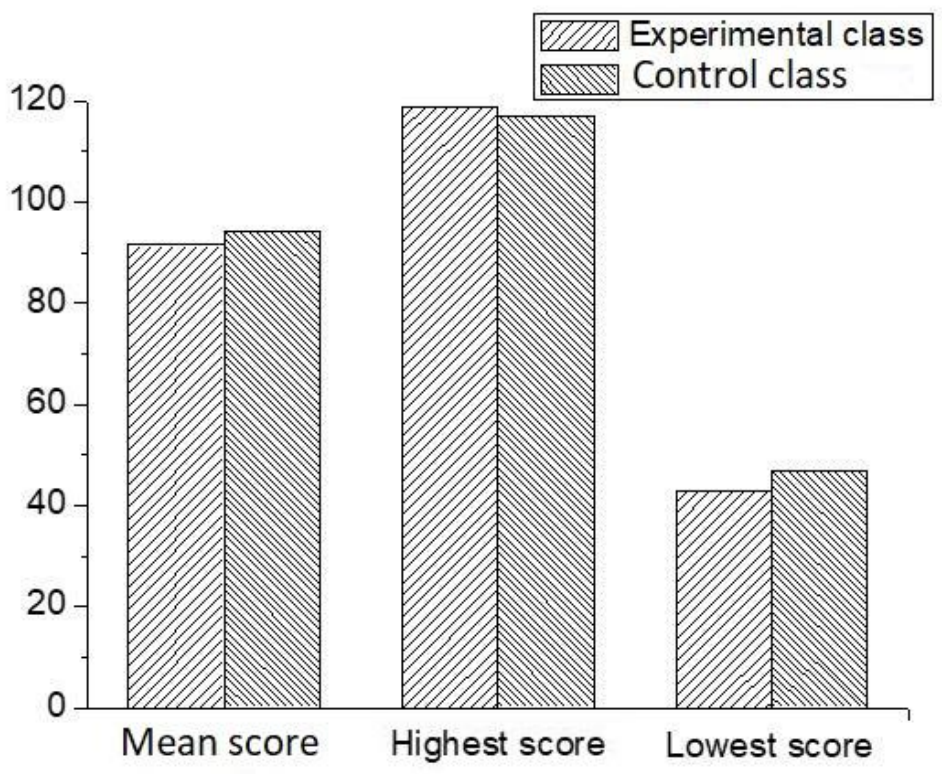

Fig. 6. Comparison of English proficiency before the experiment

Considering the learning situation and teaching contents, the teacher of the experimental class taught English by such methods as stratified teaching and inquiry-based teaching. With the aid of the MCT, the teacher prepared the teaching contents into audiovisual materials, e.g. slides and micro-lectures, and published them to students on online teaching platform, creating a new learning environment with students as the center. Fig. 7 shows a slide prepared by the teacher.

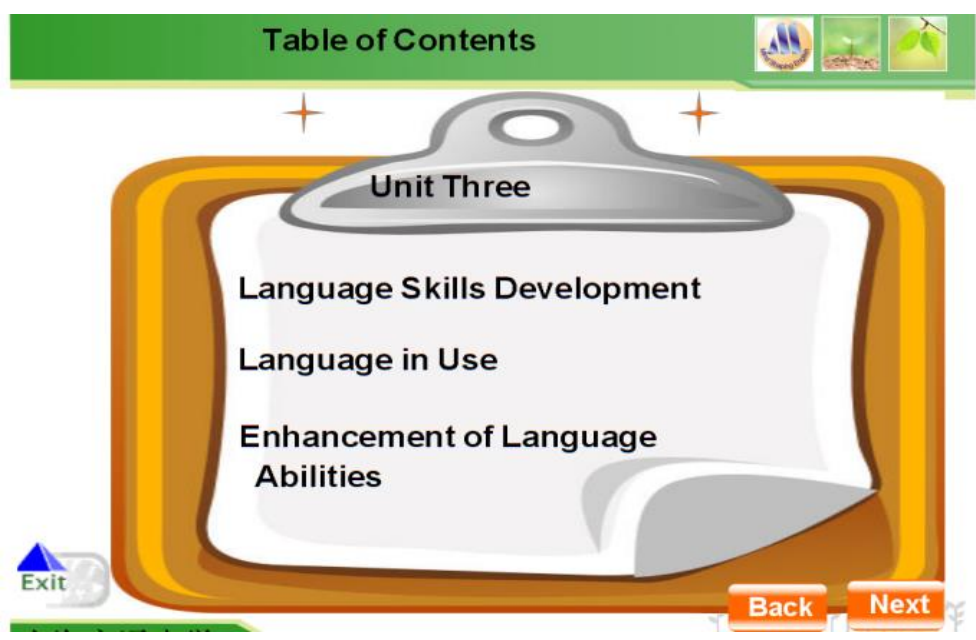

Fig. 7. A slide for personalized English teaching 


\section{Pre-class personalized preview}

Teacher: The purpose of pre-class preview is to change aimless learning into learning with questions [14]. Considering the learning situation and features of each student, the teacher provided a variety of preview materials, and prepared/uploaded different sets of test questions for preview and review, which can be selected flexibly by students. In addition, the teacher tutored the students and answered their questions via the online platform, and monitored the learning activities on the platform, including the selection of preview materials, the completion of preview tasks, and the communication between students.

Students: After logging on the online platform, the students chose the most suitable material for preview, and answered the preview test questions. The platform rated their answers and provided the suggested answers, showing the students their preview effect. Then, the students marked their mistakes and doubts, and discussed them online with classmates and teachers.

In-class personalized Q\&A: Through the online platform, the teacher learned about the preview effect and mistakes of students. During the class, he/she explained the common mistakes in class, and answered the uncommon ones via one-on-one tutoring. Of course, the Q\&A process could also be implemented in the form of group teaching.

Post-class personalized review

Stratified and individualized learning: The teacher classified the students into three levels (A, B and C) based on the following factors: the skills of listening, speaking, reading, and writing, English test scores, and the attitude, ability and method of learning [15]. For students on each level, the teacher prepared a set of post-class review questions and exercises, and offered targeted tutoring.

Similarly, the performance of students was not evaluated solely based on the total score, but also considering the progress [16]. Take level C students for example. These students have a poor foundation and low interest in English, and were encouraged to stimulate their interest and confidence in English learning.

Personalized interest cultivation: The teacher tried to discover the interest of each student and guided him/her to integrate the interest into English learning, aiming to arouse his/her enthusiasm of English learning. There is no fixed pattern for the integration, as long as the learning contents are related to the knowledge to be learned. For instance, the students interested in writing were asked to write on a given topic in English. Other tools to integrate interest in English learning include cosplay and mind mapping.

Personalized data analysis and feedback: Any student activity on the online platform, whether it is learning, testing or communication, produces data. To facilitate personalized teaching, this paper adopts content analysis and social network analysis [17] to analyze the personalized data generated by each student, and feeds back them to the teacher. Such data include learning contents, learning time, test scores and communication data. Then, the teacher could make timely adjustment to the teaching method and contents, in the light of the learning situation. Meanwhile, each student could learn about his/her situation of English learning, and adjust his/her learning 
method in a timely manner. Fig. 8 lists the post-class exercise scores of students on different levels in the experimental class.

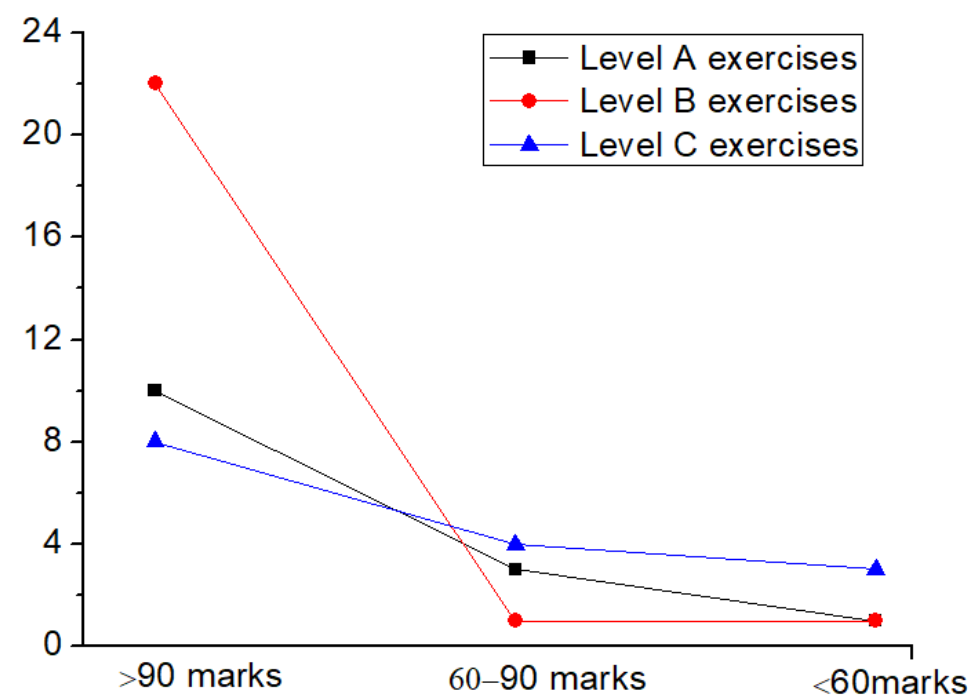

Fig. 8. The post-class exercise scores of students on different levels in the experimental class

\subsection{Effect analysis}

Test scores: Table 1 compares the independent samples t-test results on the midterm and final test scores of experimental and control classes. It can be seen that the students in the experimental class had the higher scores in both tests. The score difference was not significant in the midterm test $(\mathrm{p}=0.587>0.05)$, but very significant in the final test $(\mathrm{p}=0.048>0.05)$. The comparison shows that the MCT-based personalized English teaching design helps to improve the English performance.

Table 1. Comparison of the independent samples t-test results on the midterm and final test scores of experimental and control classes

\begin{tabular}{|l|c|c|c|c|}
\hline \multicolumn{1}{|c|}{ Item } & $\begin{array}{c}\text { Experimental class } \\
(\mathbf{M} \pm \text { SD) }\end{array}$ & $\begin{array}{c}\text { Comparison class } \\
(\mathbf{M} \pm \text { SD) }\end{array}$ & T & p \\
\hline Midterm test score & $92.433 \pm 18.643$ & $90.432 \pm 18.786$ & 0.532 & 0.587 \\
\hline Final test score & $96.134 \pm 19.654$ & $92.239 \pm 19.853$ & 0.473 & 0.048 \\
\hline
\end{tabular}

Learning attitude: The teaching effect is directly related to learning efficiency and attitude [18]. Fig. 9 records the changes of experimental class in the learning attitude before and after the experiment. Obviously, the learning attitude of the students was greatly improved through the experiment. This means the MCT-based personalized English teaching design can arouse the learning interest in English. 


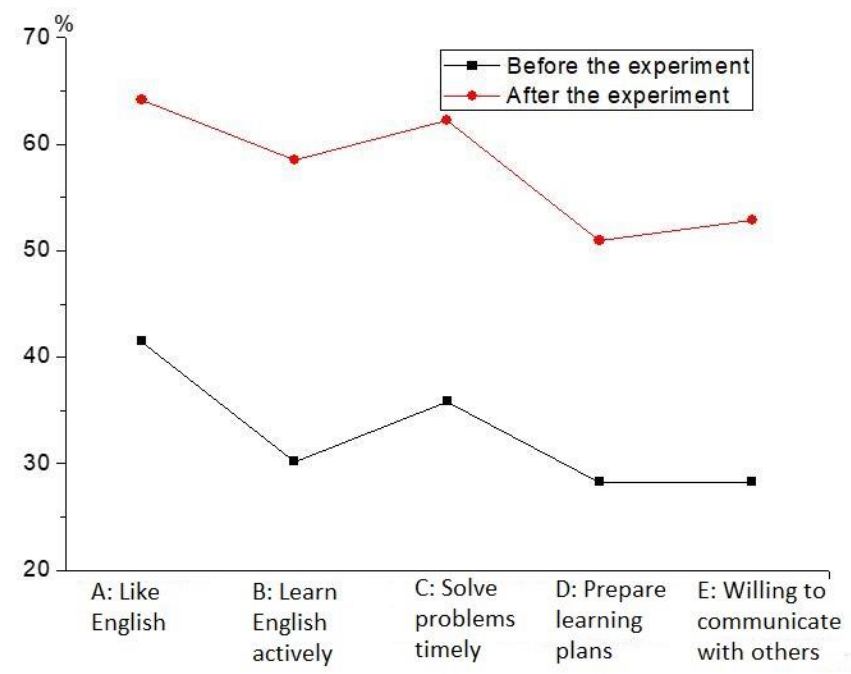

Fig. 9. The changes of experimental class in the learning attitude before and after the experiment

Learning strategy: Fig. 10 compares the learning strategies of the experimental class before and after the experiment. An obvious change in the learning strategy of English was observed, after implementing the MCT-based personalized English teaching design. Through the experiments, the students became willing to preview before class and complete homework, formulated a knowledge framework after learning, selected pertinent learning resources, learned from the experience of classmates, and communicated frequently with teachers.

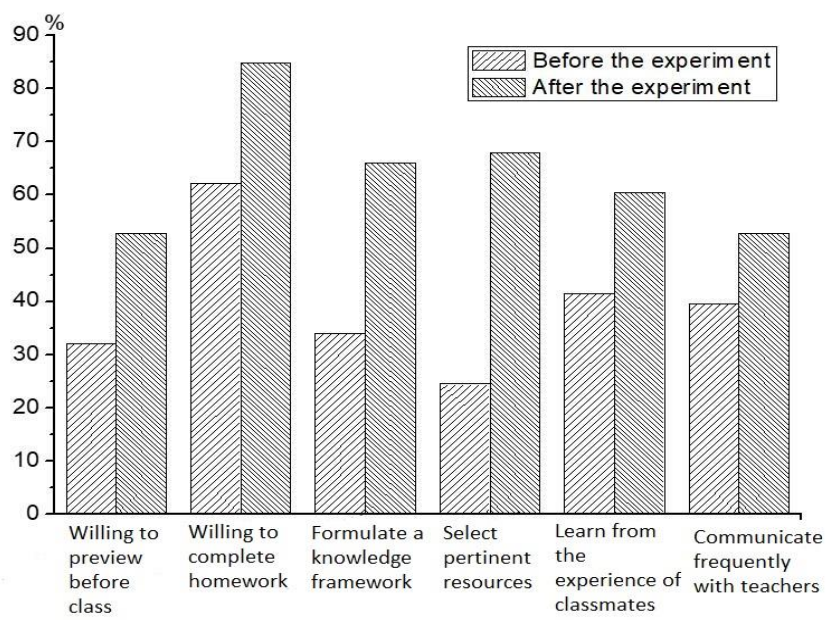

Fig. 10.Comparison of the learning strategies of the experimental class before and after the experiment 
Satisfaction: Fig. 11 presents the survey results on how satisfied the experimental class is with the MCT-based personalized English teaching design. It can be seen that the majority $(98.8 \%)$ of students were slightly or highly satisfied with the design. The few dissatisfied students should be given special care in future, because their dissatisfaction arises from the lack of interest or poor computer literacy.

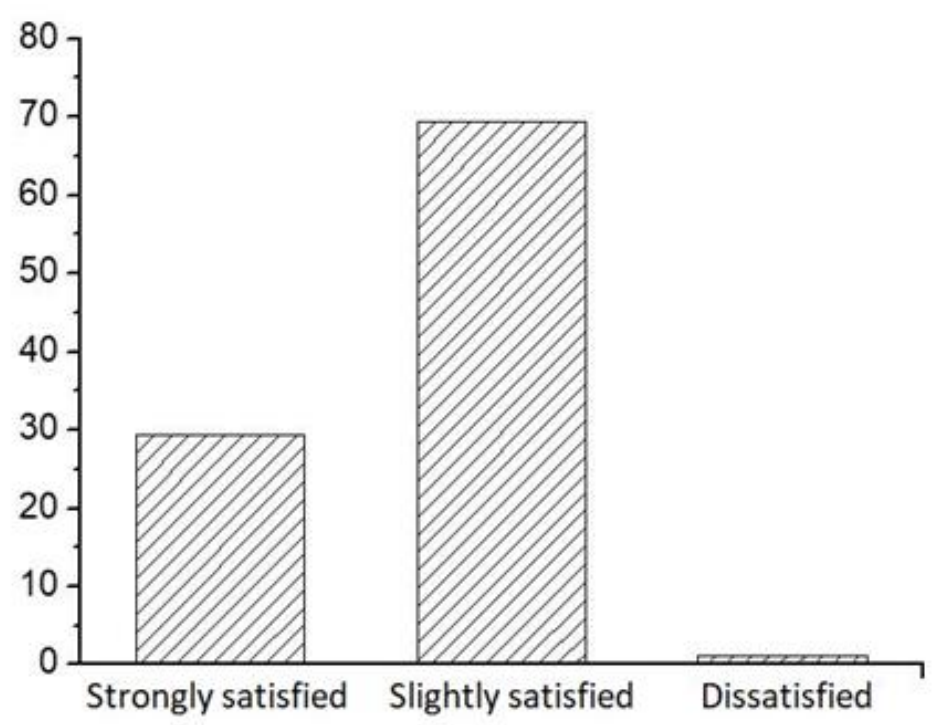

Fig. 11. Satisfaction with personalized English teaching design

\section{Conclusion}

1. In the Internet age, the proliferation of the MCT brings new opportunities to personalized English teaching in colleges. This paper mainly develops an MCT-based personalized English teaching design. The main conclusions are as follows:

2. According to the questionnaire survey on the current status of college English teaching, the major problems in the current teaching mode of college English include: some students have incorrect cognition and attitude of English learning, the teachers mostly rely on only one MCT tool (electronic whiteboard), the teaching resources are not diversified, the teaching process is not sufficiently individualized, and teachers and students rarely communicate with each other.

3. Based on the survey results, the authors developed and implemented the MCTbased personalized English teaching design from five aspects: teaching preparation, pre-class personalized preview, in-class personalized Q\&A, post-class personalized review, and personalized data analysis \& feedback.

4. Through contrastive experiment, the MCT-based personalized English teaching design was proved to have the following functions: improving the interests and performance of English learning, and cultivating a good learning habit. 


\section{$5 \quad$ References}

[1] Brostow, W., Celinski, O. (1978). Evaluation variables in personalized teaching and the sharing of records with students. IEEE Transactions on Education, 21(4): 236-240. https:// doi.org/10.1109/te.1978.4321252

[2] Swanson, D. H., Denton, J. J. (1977). Learning for mastery versus personalized system of instruction: a comparison of remediation strategies with secondary school chemistry students. Journal of Research in Science Teaching, 14(6): 515-524. https://doi.org/10.1002/ tea.3660140605

[3] Light, M., Maybury, M. T. (2002). Personalized multimedia information access. Communications of the ACM, 45(5): 54-59. http://dx.doi.org/10.1145/506218.506246

[4] Loeb, S. (1992). Architecting personalized delivery of multimedia information. Communications of the ACM, 35(12): 39-47. https://doi.org/10.1145/138859.138862

[5] Bharat, K., Kamba, T., Albers, M. (1998). Personalized, interactive news on the web. Multimedia Systems, 6(5): 349-358. https://doi.org/10.1007/s005300050098

[6] Al-Abri, A., Al-Khanjari, Z., Jamoussi, Y., Kraiem, N. (2019). Mining the students' chat conversations in a personalized e-learning environment. International Journal of Emerging Technologies in Learning, 14(23): 98-124. https://doi.org/10.3991/ijet.v14i23.11031

[7] Jarvis, H. (2006). Issues of computer-mediated communication for english language teaching. British Journal of Educational Technology, 37(4): 643-645. https://doi.org/10.11 11/j.1467-8535.2006.00592.x

[8] Celik, S. (2013). Internet-assisted technologies for english language teaching in turkish universities. Computer assisted language learning, 26(5): 468-483. https://doi.org/10.1080/ $\underline{09588221.2012 .692385}$

[9] Han, M., Niu, S. (2019). Effect of computer multimedia assisted word annotation on incidental vocabulary acquisition of English reading. International Journal of Emerging Technologies in Learning, 14(13): 21-32. https://doi.org/10.3991/ijet.v14i13.10705

[10] Aronin, L., Spolsky, B. (2010). Research in English language teaching and learning in Israel (2004-2009). Language Teaching, 43(3): 297-319. https://doi.org/10.1017/s026144 $\underline{4810000042}$

[11] Aharony, N. (2007). The use of deep and surface learning strategies among students learning english as a foreign language in an internet environment. British Journal of Educational Psychology, 76(Pt 4): 851-866. https://doi.org/10.1348/000709905x79158

[12] Porto, M., Montemayor-Borsinger, A., López-Barrios, Mario. (2016). Research on English language teaching and learning in Argentina (2007-2013). Language Teaching, 49(3): 356-389. https://doi.org/10.1017/s0261444816000094

[13] Fay, A. L., Mayer, R. E. (1994). Benefits of teaching design skills before teaching logo computer programming: evidence for syntax-independent learning. Journal of Educational Computing Research, 11(3): 187-210. https://doi.org/10.2190/5mn5-p7lw-jrb4-w9t5

[14] Pete, S. (2008). Call dimensions: options and issues in computer-assisted language learninga practical guide to using computers in language teaching. ELT Journal, 62(1): 102-105. https://doi.org/10.1093/elt/ccm086

[15] Ware, P. D., Kramsch, C. (2005). Toward an intercultural stance: teaching German and English through telecollaboration. The Modern Language Journal, 89(2): 190-205. https:// doi.org/10.1111/j.1540-4781.2005.00274.x

[16] Kozar, O. (2012). Use of synchronous online tools in private English language teaching in Russia. Distance Education, 33(3): 415-420. https://doi.org/10.1080/01587919.2012.723 $\underline{164}$ 
[17] Cyrus, L. (2008). English corpora under Japanese eyes (review). Language, 83(4): 920921. https://doi.org/10.1353/lan.2008.0022

[18] Celik, S. (2013). Internet-assisted technologies for English language teaching in turkish universities. Computer assisted language learning, 26(5): 468-483. https://doi.org/10.1080/ $\underline{09588221.2012 .692385}$

\section{Author}

Yan Zhao was born on 9th, December,1984 in Jinan City, Shandong Province, China. She received B.A. degree of English from China University of Petroleum in 2007 and M.A. degree in English Language and Literature from China University of Petroleum in 2009. She started her teaching career in August, 2009 in Yantai Nanshan University. Since 2009, she has authored 6 papers in English teaching, literature and linguistics and participated in a project.

Article submitted 2020-02-11. Resubmitted 2020-04-01. Final acceptance 2020-04-04. Final version published as submitted by the authors. 